\title{
Apocalyptic and Trans-confessional Aspects of the Rebellion of Börklüice Mustafa and Sheikh Bedreddin: Problems of Interpretations and New Vistas for Research
}

\author{
Yuri Stoyanov*
}

\section{Özet}

1416'da (sırasıyla Batı Anadolu ve Balkanlarda) gerçekleşen Börklüce Mustafa ve Şeyh Bedreddin isyanları erken Osmanlı dönemi ve Osmanlı fetret devri sürecinde önemli bir perdedir. Ancak bulguların parçalı doğası bu olayların varlık nedenlerini ve süreçlerini ayrıntılı bir şekilde yeniden anlamaya hâlâ izin vermiyor. Bir yandan son dönemde bu hareketlere dair kaynakların genişlemesi (çok farklı ideolojik ve yöntemsel yaklaşımlarla çözümlenen ve okunan) isyanların toplumsal ve siyasal yönlerini daha iyi anlamaya yardımcı olmuş, bir yandan da konunun zorlayıcı dinsel yönleri giderek daha fazla bilimsel çalışmanın ve genel ilginin odağına yerleşmiştir. Bu makale, Bizans/Balkan Ortodoks ve erken Osmanlı dinsel yaşamı ve dinler arası bağlantılar bağlamında kıyametçi, mistik ve milenaryan eğilimler hakkında yapılan araştırmaların ortaya çıkardığı yeni bilgilerden hareketle bunların temelindeki olası kıyametçi, ütopik ve inançlar arası kökenleri ve bunların ortaya çıkışına dair tartışmaları incelemeyi amaçlamaktadır.

Anahtar sözcükler: Osmanlı tarihyazımı, kıyametçilik, Hıristiyan-Müslüman ilişkileri, toplumsal hareketler ve devrimler, köylü hareketleri

\begin{abstract}
The uprisings of Börklüce Mustafa and Sheikh Bedreddin in 1416 (respectively in Western Anatolia and the Balkans) represent a significant episode in the early Ottoman era and Ottoman interregnum but the fragmentary nature of the evidence still do not permit a detailed reconstruction of their raison d'être and course. Widening the exploration of the source base for these movements in the last few decades has allowed for a better understanding of the social and political aspects of the rebellions (approached and interpreted in diverse ideological and methodological frameworks), while the challenging problem of their religious dimension has been also the focus of increasing scholarly and general attention. Drawing on new advances in research on apocalyptic, mystical and millenarian trends in the late Byzantine/Balkan Orthodox and early Ottoman religious life and inter-religious contacts, the article intends to delineate the possible pedigree of their apocalyptic, utopian and trans-confessional underpinnings as well as the debates surrounding their provenance.
\end{abstract}

Keywords: Ottoman historiography, apocalypticism, Christian-Muslim interrelations, social movements and revolutions, peasant movements

\footnotetext{
* University of London, SOAS
} 
The outbreak, course and suppressions of the rebellions of Börklüce Mustafa and Sheikh Bedreddin in 1416 still pose some of the most intricate religious and historiographic problems of the early Ottoman era in the Balkans and Anatolia. The uprisings broke out in the aftermath of the turbulent period of the Ottoman interregnum and civil war (1402-1413) which came in the wake of the defeat by Timur's Mongol army of Bayezid I's Ottoman forces (reinforced with his vassals) at Ankara in 1402. The study of this period has enjoyed various promising advances of research ${ }^{1}$ but the current state of evidence still does not allow a satisfying and detailed reconstruction of the provenance and exact chronology of these uprisings. The study of this period has lately enjoyed various promising advances of research but the current state of evidence still does not allow a satisfying and detailed reconstruction of the provenance and exact chronology of these uprisings. Further widening the exploration of the source base for the principal instigators, leadership, organisation and justification of the rebellions, as well as for the main social groups which came to comprise the two (Balkan and Anatolian) rebellious movements is certainly a requirement for a better understanding of their socio-political and religious dynamics.

Notwithstanding the social and political aspects of the rebellions (which have been approached and interpreted in a variety of often contrasting ideological and methodological frameworks), their intriguing religious dimension has been for some time the focus of increasing scholarly and general attention. An objective and cautious analysis of the evidence of the religious agendas of the leaders and main protagonists of the rebellions is of direct relevance to the ongoing and intensifying debates on the (insufficiently illuminated as yet) religious processes and transformations in the urban centres and rural regions integrated into the expanding early Ottoman state. These processes include, of course, the convoluted and highly controversial area of the nature of Christian-Muslim interrelations on both elite and popular levels in the early Ottoman Balkans and western Anatolia.

On the one hand, progress in research on the religious climate of the early Ottoman empire (before the eventual more thorough Sunnization of Ottoman ruling establishments and what has been described as the parallel Shi itization of the Anatolian Kızlbaş communities in the late fifteenth and sixteenth century) increasingly shows that it was characterized by fluidity and diversity and Shi ite-Sunni religious and spiritual borders in particular were often fluctuating and permeable rather than fixed. ${ }^{2}$ Thus

1 See, for example, the recent reconstruction of the political and military developments of the period and its specific political culture in Dimitris J. Kastritsis, The Sons of Bayezid, Empire Building and Representation in the Ottoman Civil War of 1402-1413 (Leiden and Boston: Brill, 2007).

2 Cf., for example, Cemal Kafadar, Between Two Worlds: The Construction of the Ottoman State (Berkeley-Los Angeles-London: University of California Press, 1995), 76, passim; Derin Terzioğlu, "Sufis in the Age of State-Building and Confessionalization," in The 
early Ottoman Islam seems a more heterogeneous phenomenon, with pronounced syncretistic, antinomian and Shicite-related/leaning trends, which could provoke religious ferment and religio-political opposition and movements against the centralization policies of the emerging empire. Among other developments, during this period the main currents of Anatolian Sufism were evolving, either in their formative phases or already had entered the transition leading towards their eventual institutionalization and further growth in the following centuries. ${ }^{3}$

On the other hand, in the last few decades promising avenues for research (originally opened in the late Ottoman period) have been increasingly and successfully exploited to enhance the study of the development of Christian-Islamic syncretism in the Ottoman era and particular controversial but important problems such as the involvement of the dervish orders in this long-term process. One of these avenues is the evolving study of the inter-relations and cross-fertilization between the different local varieties of Christianity and Islam, especially in the sphere of the shared sanctuaries, saints and feasts or some superstitious and quasi-magic beliefs and practices. Consequently, a significant amount of evidence has been accumulated showing that ordinary and mostly illiterate Christians and Muslims (especially those inhabiting the rural Balkan and Anatolian areas of the Ottoman empire) could amalgamate and synthesize their respective beliefs and cultic practices much more easily than (and often lacking the theological bias and reservations of) their corresponding intellectual and religious elites. ${ }^{4}$

The question of whether major Ottoman-era religious and political figures and establishments (mainline, marginal or those seen as heterodox) attempted a rapprochement and/or equivalentism between Islam and Christianity (whether applied in a proselytizing framework

Ottoman World, ed. C. Woodhead (New York: Routledge, 2011), 86-10o.

3 The process of the migration and re-settlement of Sufi groups into Anatolia proceeded with various intensity from the beginning of the twelfth century onwards -see the wide-ranging reassessment of the extant evidence and recent scholarship in Ahmet Karamustafa, "Kalenders, Abdâls, Hayderîs: The Formation of the Bektâşîye in the Sixteenth Century," in Süleyman the Second and his Time, eds. H. Inalcik and C. Kafadar (Istanbul: Isis Press, 1993), 121-29; Karamustafa, God's Unruly Friends: Dervish Groups in the Islamic Later Middle Period, 1200-1550 (Salt Lake City: University of Utah Press, 1994, repr. Oxford, 2006); Karamustafa, "Origins of Anatolian Sufism," in Sufism and Sufis in Ottoman Society: Sources, Doctrine, Rituals, Turuq, Architecture, Literature and Fine Arts, Modernisms, ed. A. Y. Ocak (Ankara: Atatürk Supreme Council for Culture, Language and History, 2005), 67-95.

4. The collection and preliminary analysis of much valuable material on this phenomenon by Frederick William Hasluck (1878-1920): Frederic W. Hasluck, Christianity and Islam under the Sultans, 2 vols. (Oxford: Clarendon Press, 1929), has been followed by a succession of studies and publications of further evidence of these syncretistic phenomena or reappraising Hasluck's earlier assembled data and conclusions - see, for example, the various contributions in David Shankland, ed., Archaeology, Anthropology and Heritage in the Balkans and Anatolia: the Life and Times of F.W. Hasluck, 1878-1920, 3 vols. (Istanbul: Isis Press, 2004-2013). 
or employed as underpinning religio-political programmes) has proven more controversial and remains vigorously debated. Such debates, arguments and counter-arguments have accompanied the scholarly efforts to explain and contextualize the reports in primary sources of Christian-Muslim alliances, solidarity and ecumenical-like rapport during the insurrections of Börklüce Mustafa and Sheikh Bedreddin (better recorded in the case of the movement of Börklüce Mustafa). What has added further "topicality" and significance to the reported trans-confessional aspects of the insurrections is the ongoing major revisions and critique of the (until recently) very influential thesis of Paul Wittek of the crucial role of the Gaza ("Holy War") and Gazi ("Holy Warrior") ethos as essentially the raison d'être of the early Ottoman state. ${ }^{5}$ While some historians have retained elements of the "Gazi thesis" in their reconstructions of early Ottoman history, ${ }^{6}$ the sustained and ongoing critique of this thesis ${ }^{7}$ has also led to a renewed focus on and reappraisals of the role of western Anatolian and Balkan Christian aristocratic and military elites (and their power-sharing networks) in Ottoman state-building and initial expansions, as well as in the eventual formation of an Ottoman polity and imperial culture.

This paradigm shift in early Ottoman studies has also necessitated

5 Paul Wittek, The Rise of the Ottoman Empire (London: Routledge, 1938).

6 See, for example, Halil İnalcık, The Ottoman Empire: The Classical Age, 1300-160o (London: Weidenfeld and Nicholson, 1973); İnalcık, "The Question of the Emergence of the Ottoman State," International Journal of Turkish Studies 2, no. 2 (1981-82): 71-79; İnalcık, "Introduction: Empire and Population," in An Economic and Social History of the Ottoman Empire, 1300-1914, eds. H. İnalcık and D. Quataert (Cambridge: Cambridge University Press, 1994), 11-12; Elizabeth Zachariadou, "Histoire et légendes des premiers Ottomans," Turcica, 23 (1995): 45-89.

7 See, among others, Speros Vryonis, The Decline of Medieval Hellenism in Asia Minor and the Process of Islamization from the Eleventh through the Fifteenth Century (Berkeley: University of California Press, 1971); Rudi P. Lindner, Nomads and Ottomans in Medieval Anatolia (Bloomington: Indiana University Press, 1983); Lindner, "Stimulus and Justification in Early Ottoman History," Greek Orthodox Theological Review 27 (1982): 207-24; Lindner, Explorations in Ottoman Prehistory (Ann Arbor: University of Michagan Press, 2007); Pal Fodor, "Ahmedi's Dasitan as a Source of Early Ottoman History," Orientalia Hungaricae 38 (1984): 41-54; Ronald C. Jennings, "Some Thoughts on the GaziThesis,” Wiener Zeitschrift für die Kunde des Morgenlandes 76 (1986): 151-61; Colin Imber, “The Ottoman Dynastic Myth," Turcica 19 (1987): 7-27; Imber, The Ottoman Empire, 13001481 (Istanbul: Isis Press, 1990), 12-13; the relevant contributions in Colin Heywood and Colin Imber, eds., Studies in Ottoman History in Honor of Professor V.L. Ménage (Istanbul: Isis Press, 1994); Colin Heywood, "A Subterranean History: Paul Wittek (1894-1978) and the Early Ottoman State," Die Welt des Islams, New Series 38/3 (1998): 386-4.05; Linda T. Darling, "Contested Territory: Ottoman Holy War in Comparative Perspective," Studia Islamica 91 (2000): 133-64; Darling, "Reformulating the Gazi Narrative: When Was the Ottoman State a Gazi State?” Turcica 43 (2011): 13-53; Heath W. Lowry, The Nature of the Early Ottoman State (Albany: SUNY Press, 2003); Ali Anooshar, The Ghazi Sultans and the Frontiers of Islam (London and New York: Routledge, 2009), 1-15 and 118-65; see the recent summary of the debate in Kastritsis, The Sons of Bayezid, 12-22. See also Colin Heywood, "Introduction: Critical Essay," in P. Wittek, The Rise of the Ottoman Empire: Studies in the History of Turkey, 13th-15th Centuries, ed. C. Heywood (London and New York: Routledge, 2012), 1-28. 


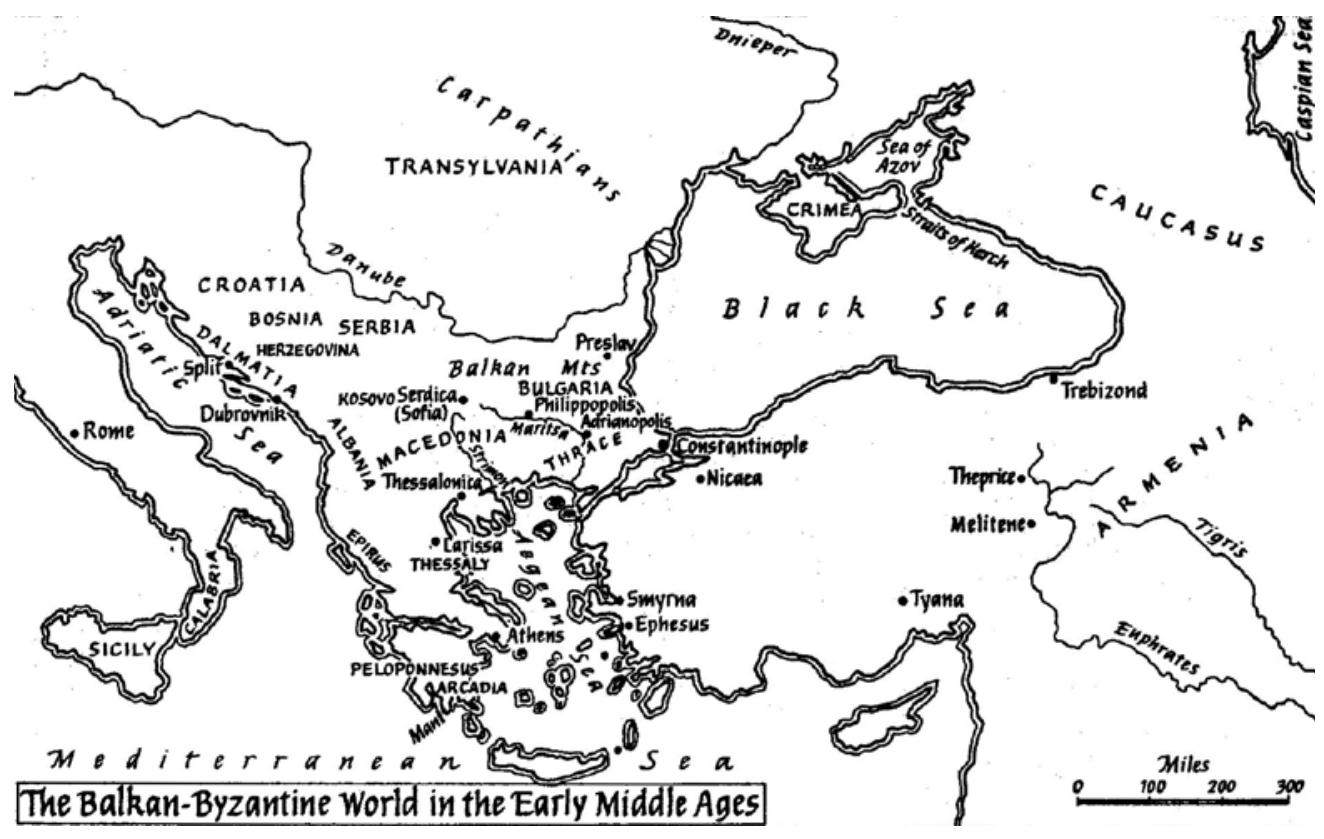

Source: The Other God: Dualist Religions from Antiquity to the Cathar Heresy (New Haven, Conn.; London: Yale University Press, 2000). Reproduced courtesy of Yale University Press, London.

reassessments of the evidence of early Ottoman religious and ideological attitudes to Christianity and the Christian powers that they encountered in western Anatolia and the politically fragmented Balkans, whether as their adversaries, allies or vassals. A series of valuable analyses of the already known or newly available written evidence and archaeological record have addressed the crucial question of whether these attitudes were dictated by pragmatic political and economic considerations or by a religious zeal to fight "the infidel", as forcefully asserted by the classical formulations of the "Gazi thesis." All this accumulation of new material and explanatory models has led to more nuanced understanding of what the notion of "Gaza" warfare actually meant to the various social, tribal and religious groups and networks of the characteristic western Anatolian frontier societies from which emerged the expansive Ottoman emirate. Fresh light was shed on the evolving usage of "Gaza" references and labelling in Ottoman rhetoric and practice (as justification of the use of armed force), including its exploitation as a legitimization dynastic myth in works such as the fifteenth-century Ottoman court chronicles.

Among these new trends of research, studies seeking to identify and define distinct patterns of conscious syncretism and specific forms of Christian-Islamic "ecumenism" in the religious inter-relations/dialogue of the early Ottoman era seem particular relevant to the continuing efforts to uncover at least some aspects of the intriguing but elusive religious agendas of the Börklüce Mustafa and Sheikh Bedreddin insurrections. 
Approaches which have tended to emphasize the Byzantine/Christian contribution (apart from the Seljuk and Ilkhanid impact) to the inclusive socio-political "syncretism" of the early Ottoman state's political and military administration have also led to some searching questions as to whether a corresponding syncretism also developed in the religious and cultural spheres. ${ }^{8}$ All the more that the steady progress of the study of the preceding Seljuk era in Anatolia (1077-1308) has extended beyond the written word into areas of material culture such as art, architecture, inscriptions, coinage and battlefield and conquest archaeology to explore the chronology and nature of Christian-Muslim co-existence, interaction and symbioses during this period in greater depth. ${ }^{9}$ Symptomatically, much of this valuable material remains outside the scope and concerns of the contemporary historical chronicles and official documents, predominantly focused as they are on the grand narratives of military conquests, political events and deeds of rulers, high clerics and warrior chieftains.

Accordingly, some studies of early Ottoman history have argued that the Christian-Muslim rapprochement and alliances reported during the Börklüce Mustafa and Sheikh Bedreddin uprisings went much further than the co-existence-based symbiosis of the Seljuk era or mere fraternization of Christian and Muslim rebels along social lines. In this line of argument, the insurrections represent a manifestation of a religio-political IslamicChristian synthesis, which had been developing among both the ruling elites and rural communities in the early stages of Ottoman conquest. ${ }^{10}$ The

8 Herbert A. Gibbons, The Foundation of the Ottoman Empire: a History of the Osmanlis up to the Death of Bayezid I (1300-1403) (Oxford: The Century 1916); Speros Vryonis, "The Byzantine Legacy and Ottoman Forms," Dumbarton Oaks Papers 23/24 (1969/1970): 251308.

9 See the syntheses of the evidence in Mitchel Balivet, Islam mystique et révolution armée dans les Balkans ottomans: Vie du cheikh Bedreddin, le "Hallâj des Turcs", 1358/59-1416 (Istanbul: Editions Isis, 1995), 5-35; Keith Hopwood, "Christian-Muslim Symbiosis in Anatolia", in Archaeology, Anthropology and Heritage, in the Balkans and Anatolia, ed. D. Shankland (Istanbul: Isis Press, 2004-2013), 13-30; see the contributions in A. C. S. Peacock, Bruno De Nicola and Sara Nur Yıldız, eds., Islam and Christianity in Medieval Anatolia (Burlington, VT: Ashgate, 2015).

10 Lowry, The Nature of the Early Ottoman State, esp. 131-44; Karen Barkey, Empire of Difference: the Ottomans in Comparative Perspective (Cambridge, New York: Cambridge University Press, 2008), 169-76 (Barkey provides a sociologiocal framework to this thesis). Cf. the view of E. Zachariadou that Sheikh Bedreddin's "revolution" aimed to establish a "state based on a new religion derived from both Islam and Christianity." Elizabeth Zachariadou, "Religious Dialogue Between Byzantines and Turks During the Ottoman Expansion," in Religionsgesprache im Mittelalter, eds. B. Lewis and F. Niewöhner (Wiesbaden: Otto Harassowitz, 1992), 301-02. A comparable and earlier version of this theory has been applied to the regime of one of the Ottoman princes of the interregnum period, Musa Çelebi, in the Balkans (he acted as a co-sultan and reigned over the European/Balkan Ottoman provinces in 14,11-14,13 and appointed Sheikh Bedreddin as a chief military judge, kadıasker, in 1411) in Paul Wittek, "De la défaite d'Ankara à la prise de Constantinople," Revue des etudes Islamiques 12 (1938): 21-24; see the critique of this approach to Musa Çelebi's reign and policies in Colin Imber, "Paul Wittek's De la défaite d'Ankara à la prise de Constantinople," Osmanlı Araştırmalarl 5 (1986): 65-81. Cf. also 


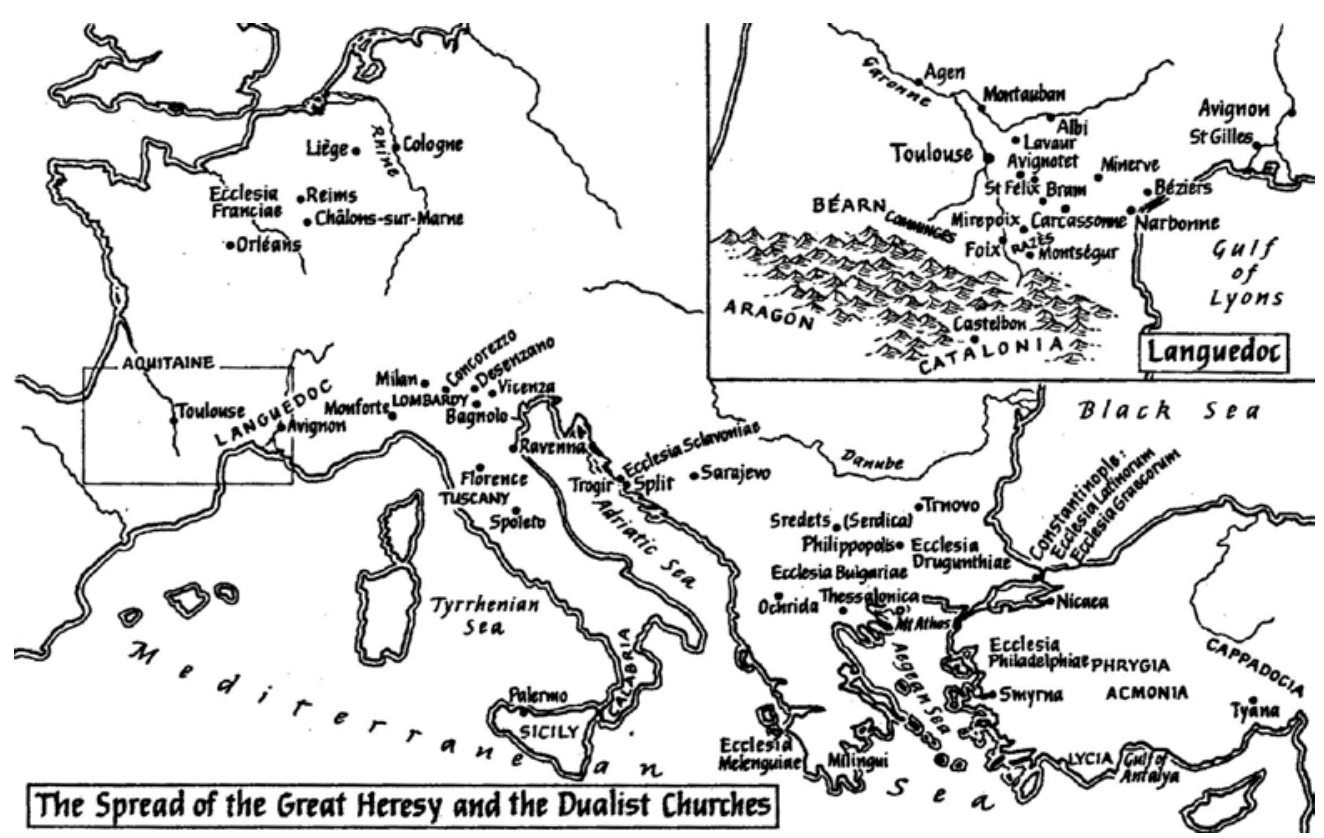

Source: The Other God: Dualist Religions from Antiquity to the Cathar Heresy (New Haven, Conn.; London: Yale University Press, 2000). Reproduced courtesy of Yale University Press, London.

attempt to foster this Islamic-Christian synthesis as a reflection of the new and changing political realities in the early Ottoman Balkans and Anatolia is seen as coming into conflict with the "high" Sunni Islam of the Ottoman urban administrative structures. The latter emerged victorious from this conflict and in the following decades during the successive reigns of Murad II and Mehmed II imposed further centralization and the stricter social and religious order of institutionalized Sunni Islam.

This is an attractively structured theory (and they are certainly a few precedents of such developments in regions newly annexed to Islamic rule) which draws on recent developments in the study of primary written sources and records of the material culture of the early Ottoman era, a notoriously difficult and controversial area which still abounds in massive gaps and insurmountable research problems at present. ${ }^{11}$

Niketas Siniossoglou's thesis of that Sheikh Bedreddin's syncretistic religio-political reformism represented "an attempt at unifying the three Abrahamic monotheistic religions into a universal religion destined to subvert the Ottoman establishment." Niketas Siniossoglou, "Sect and Utopia in Shifting Empires: Plethon, Elissaios, Bedreddin," Byzantine and Modern Greek Studies 36/1 (2012): 51-52.

11 See, for example, the well-known definition of the earliest history of the Ottomans as a "black hole", with any attempt to fill it, resulting "simply in the creation of more fables." Colin Imber, "The Myth of Osman Gazi," in The Ottoman Emirate (1300-1389), ed. E. Zacharoadou (Rethymon: Crete University Press, 1993), 75. 


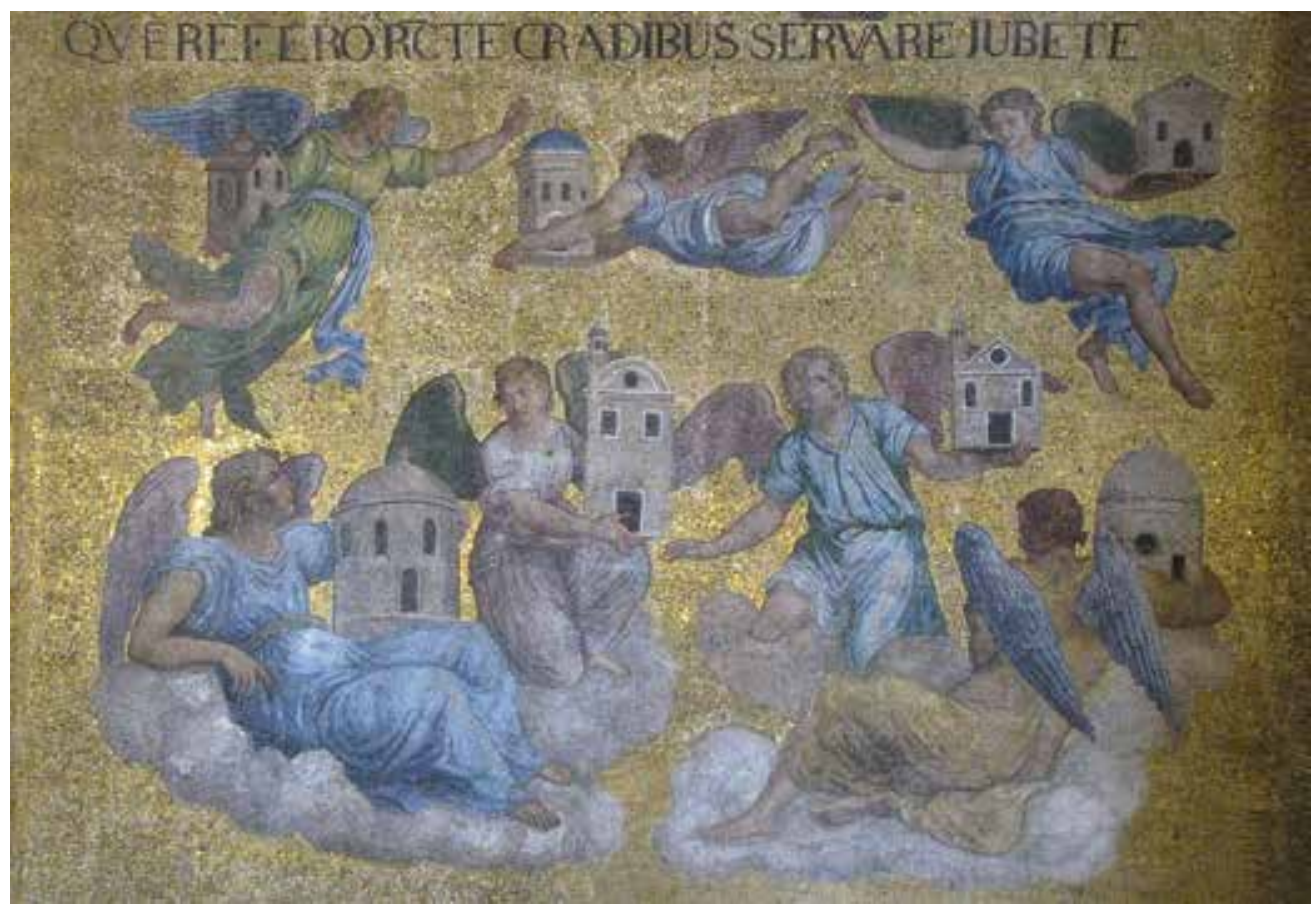

The angels standing guard to the seven churches of Asia.

Mosaic in the Patriarchal Cathedral Basilica of Saint Mark, Venice, Italy. Public domain.

Accordingly, the proponents of this theory admit that in view of the current state of evidence, it remains a "highly speculative" alternative to the construction of early Ottoman political and religious history in later Ottoman sources. ${ }^{12}$ The other major problem is that the evidence of the Sheikh Bedreddin rebellion in the Balkans is insufficient to allow a conclusive reconstruction of Christian participation in its organization and abortive course. Hence the direct and circumstantial evidence of Christian involvement in and support for the Börklüce Mustafa insurrection in the Anatolian Aegean coastal area acquires even more importance, though the local Anatolian characteristics (despite some parallels) differed in a number of important respects from the north-eastern and eastern Balkans traversed by Sheikh Bedreddin in preparation for the armed rebellion.

Both early and current research on Börklüce Mustafa's rebellion have focused and spent much effort on identifying and reconstructing the social, socio-economic, political and religious realities behind the account of the insurrection in Doukas' Historia Turko-Bizantina, ${ }^{13}$

12 Lowry, The Nature of the Early Ottoman State, 143.

13 Michael Doukas, Historia Turko-Bizantina, V. Grecu ed. and transl., Istoria TurcoBizantina (Bucharest: Editura, 1958); for the account of Börklüce Mustafa's revolt, see ch. 21: 11-14, 149-53. Translations in Harry J. Magoulias, Decline and Fall of Byzantium to 
with its assertions about the ideals of communal property, voluntary poverty and Christian-Muslim equality advocated by the rebels, as well as its messianic and prophetic aspects. In the history of the study of the Börklüce Mustafa's insurrection there has been an obvious tendency to project modern political and social concerns and/or agendas in the proposed reconstructions of the insurrection's raison d'être. This is especially visible in cases where Börklüce Mustafa's movement is regarded as entirely or predominantly a manifestation of a violent peasant, anti-feudal protest, triggered by the socio-economic conditions and intensifying socio-political conflicts in the decades of the early Ottoman conquests and the Ottoman interregnum period. This approach has been most forcefully and consistently advanced in the Eastern Block's institutionalized Marxist historiographies of the Ottoman empire during the Cold War period. ${ }^{14}$

The investigation of the social dimension of the two 1416 uprisings needs to address the valid and important question of whether Sheikh Bedreddin and Börklüce Mustafa could have joined the rebellious social movements already in progress in the Balkans and Anatolia as participants and not principal instigators, and thus the revolts were not necessarily linked to their personal beliefs and agendas. ${ }^{15}$ Parallels to a similar evolution of socio-political engagement should be indeed discernible in other popular uprisings not necessarily triggered by social and economic crises and conditions. However, the evidence of Sheikh Bedreddin's travels in Anatolia and the Balkans and his accumulation of associations with major political regional players prior to the insurrection does suggest that he was already involved in the establishment of a network of anti-Ottoman alliances with a coherent political programme which underpinned the rebellion from its onset. ${ }^{16}$ In the case of Börklüce Mustafa's role in the Anatolian revolt the evidence shows some of the obvious traits of charismatic leadership (prophetic claims, miracle-making, etc.) which find analogies both in contemporary Europe and in earlier oppositional (especially Shi'ite) movements in the Islamic world. This does not diminish the social dimension of the Börklüce Mustafa uprising, but

the Ottoman Turks / by Doukas; an annotated translation of "Historia Turco-Byzantina" by Harry J. Magoulias (Detroit: Wayne State University Press, 1975); Jean Dayantis, "Doukas, Histoire turco-byzantine. Introduction, traduction et commentaire," (PhD diss., Montpelier 3, Lille, 2004).

14. A brief treatment of references to Soviet and Bulgarian Cold War-ear historiography of the Börklüce Mustafa and Sheikh Bedreddin movement can be found in Nevena Gramatikova's contribution to this volume of conference proceedings.

15 Saygın Salgırlı, "The Rebellion of 1416: Recontextualizing an Ottoman Social Movement," Journal of the Economic and Social History of the Orient 55 (2012): 32-73.

16 Cf. Hakkı E. Çıpa, "Contextualizing Şeyh Bedreddīn: Notes on Halīl b. İsmā̄ills Menākıb-ı Şeyh Bedreddīn b. İsrāīl' (sic),” in Şinasi Tekin’in Anısina: Uygurlardan Osmanlıya (Istanbul: Laika Yayıncılık, 2005), 290; Dimitris Kastritsis, "The Revolt of Şeykh Bedreddin in the Context of the Ottoman Civil War of 14.02-1413," in Halcyon Days in Crete VII, ed. A. Anastasopoulos (Rethymno, 2012), 229-31. 
indicates that it may be difficult to isolate its social from its religious and political features. ${ }^{17}$

A further study of the social change, evolving forms of protest of the urban and rural poor, and anti-aristocratic tensions and violence in the western Anatolian and Balkan regions controlled by the Ottomans, the Aegean emirates and fractured Byzantium are undoubtedly of great importance for understanding the social provenance, composition and aspiration of the Börklüce Mustafa movement. ${ }^{18}$ But the at the same time, the growing cumulative evidence of the various sources (written and material culture records) on the political (dynastic in the case of Sheikh Bedreddin) and religious features of the Börklüce Mustafa and Sheikh Bedreddin movements also need to remain the focus of a critical analysis. The socio-economic approach alone cannot account for the complexity and diversity of this evidence, including the participation of the torlak mendicant dervishes in the Börklüce Mustafa revolt. ${ }^{19}$ Since the importance of the Börklüce Mustafa and Sheikh Bedreddin uprisings clearly transcend their immediate role in the social and economic crises, as well as political and dynastic power struggles in the early fifteenth-century Balkans and western Anatolia, such critical analysis should also profit from recent advances in the study of corresponding developments in the contemporary Eastern Mediterranean and Islamic Middle East, as well as Eastern and Western Christendom, especially in the fields of religious history and inter-religious dynamics. Arguments for parallels between (what has been defined as) the socio-religious utopianism of the Börklüce Mustafa and Sheikh Bedreddin movements, on one hand, and their contemporary, George Gemistos Plethon, on the other, ${ }^{20}$ also will need a closer analysis.

Recent research indeed indicates that the aspirations for Christian-Muslim solidarity and equality articulated in the sources for the Börklüce Mustafa and Sheikh Bedreddin movements need to be treated in the wider context of the evolving trends towards Christian-Muslim theological and religious-political rapprochement in the course of the fifteenth century. ${ }^{21}$ In view of the debate on whether the Börklüce Mustafa and Sheikh Bedreddin uprisings represented the high point of a

17 Cf. D. Kastritis comments on the impossibility of studying Sheikh Bedreddin's rebellion as "purely social, political or religious phenomenon" as it represented a combination of these characteristics, Kastritsis, "The Revolt of Şeykh Bedreddin," 238.

18 See the up-to-date analysis of these social, economic and political developments in Salgirll, "The Rebellion of 14,16."

19 On the torlak dervishes, cf. Ahmet Y. Ocak, Osmanll Toplumunda Marjinal Sufilik: Kalenderiler, XIV-XVII. Yüzyıllar (Ankara: Türk Tarih Kurumu, 1992), 74-85; Karamustafa, God's Unruly Friends, 65-67.

20 See, for example, Siniossoglou, "Sect and Utopia," 51-52.

21 As pursued in some of the studies of M. Balivet, see, for example, Mitchel Balivet, "Deux partisans de la fusion religieuse des chrétiens et des musulmans au XVe siècle," Byzantina 10 (1980):363-90. 


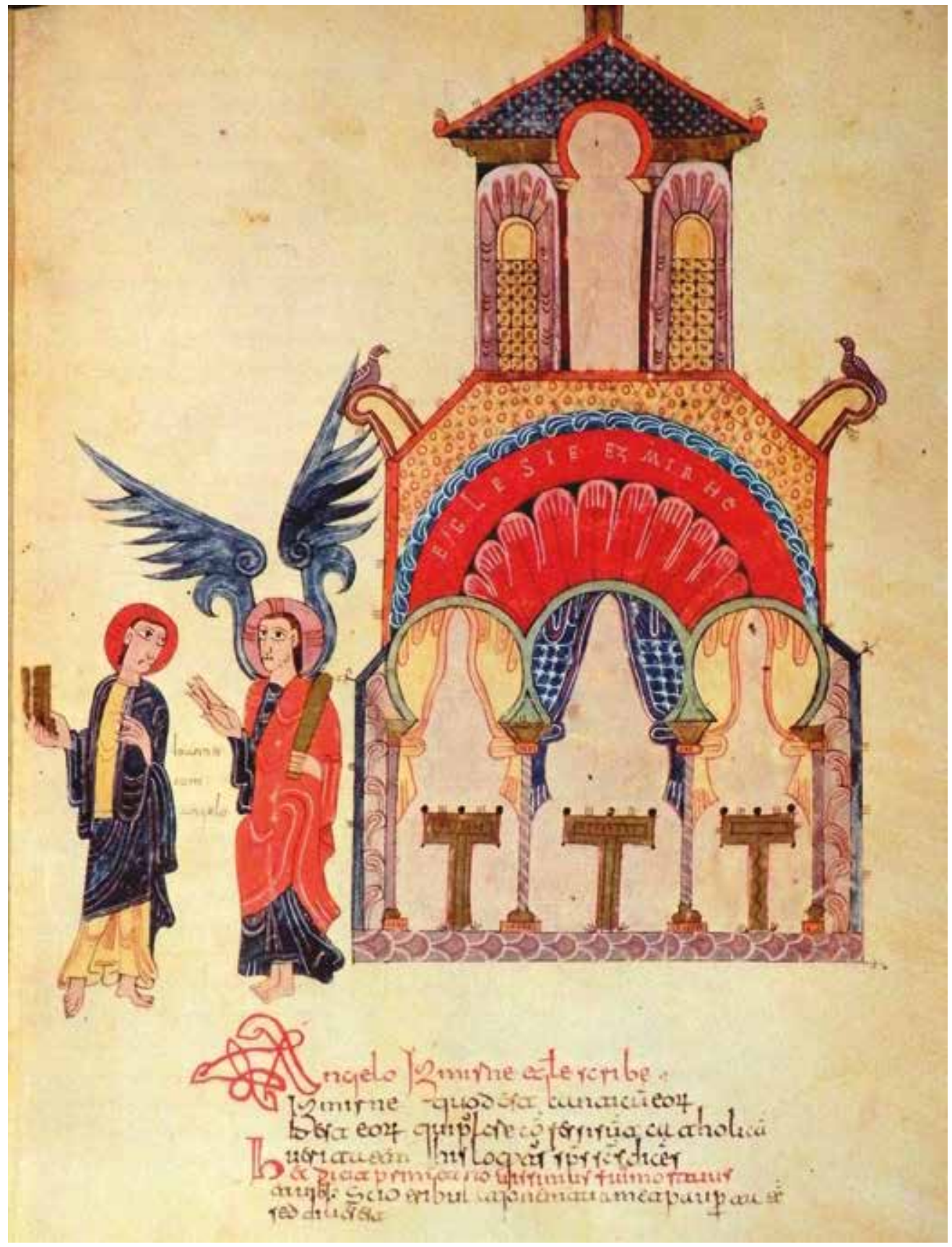

Church of Smyrna from Gerona Beatus, the Museum of the Cathedral of Girona, Catalonia, Spain. Public domain. 
movement towards "Islamochristian synthesis", new evidence-based research which has re-defined some of the earlier assumptions regarding the nature, tensions and patterns of Islamic-Christian syncretism (and anti-syncretism) ${ }^{22}$ clearly needs to be taken into close consideration. The same applies to new studies of the fourteenth and fifteenth century fortunes of those major (originally) Christian families and figures who took an active and crucial part in the early Ottoman conquests and power struggles, including those of the interregnum period. ${ }^{23}$

Given the inter-relations and inter-dependencies of the Börklüce Mustafa and Sheikh Bedreddin uprisings (repeatedly asserted in written testimonies) and the reported popularity and following of Sheikh Bedreddin in the Smyrna area, it is also vital to continue and widen the comparative survey of utopian, universalistic, prophetic messianic and egalitarian ideas in the sources for the western Anatolia uprising and teachings of Sheikh Bedreddin. The latter include Sheikh Bedreddin's own writings, the Menakıbname (composed by his grand-son, Halîl bin İsmâil), ${ }^{24}$ and the Ottoman chronicles. The Börklüce Mustafa and Sheikh Bedreddin-related accounts in the Ottoman chronicles and the Menakibname have been the focus of earlier and ground-breaking research on Sheikh Bedreddin ${ }^{25}$ and lately his own writings have been also scrutinized (with mixed success and taking into account that not all of them have been preserved and may await re-discovery) ${ }^{26}$ for notions anticipating the radical agendas of the 14,16 uprisings.

Growing research on the Menakibname, in particular, has made it possible (while critically sifting through the obvious agendas of its author) to chart the intellectual and religious evolution of Sheikh Bedreddin during his extensive travels, his eventual and intensive involvement

22 See, for example, Tijana Krstić, Contested Conversions to Islam: Narratives of Religious Change in the Early Modern Ottoman Empire (Stanford, CA: Stanford University Press, 2011), 50-75.

23 Heath Lowry, Fourteenth Century Ottoman Realities (In Search of Haci-Gazi Evrenos) (Istanbul: Bahçeşehir University Press, 2012); M. Kiprovska, "The Mihaloğlu Family: Gazi Warriors and Patrons of Dervish Hospices,” Osmanlı Araştırmaları, 32 (2008): 173-202; Kiprovska, "Byzantine Renegade and Holy Warrior: Reassessing the Character of Köse Mihal, a Hero of the Byzantino-Ottoman Borderland," in Journal of Turkish Studies 40 (2013): 245-69.

24. Halîl bin İsmâil bin Şeyh Bedrüddin Mahmûd, Sımavna Kadısıoğlu Şeyh Bedreddin Manâkıbı, eds. A. Gölpınarlı and İ. Sungurbey (Istanbul: Eti Yayınevi, 1967).

25 See respectively Franz Babinger, "Schejch Bedr ed-Dīn, der Sohn der Richters von Simāw," Der Islam 11 (1921): 1-106 (for analysis of the Börklüce Mustafa and Sheikh Bedreddin-related material in the Ottoman chronicles) and Hans J. Kissling, "Das Menāqybnāme Scheich Bedr ed-Dīn's, des Sohnes des Richters von Samāvna,” Zeitschrift der Deutschen Morgenländischen Gesellschaft 100 (1950): 112-76 (for analysis of the Menakıbame).

26 Cf., for example, Vecihi Timuroğlu, Varidat (Ankara: Türkiye Yayınları, 1979); İsmet Z. Eyüboğlu, Şeyh Bedreddin ve Varidat (Istanbul: Derin Yayınları, 1980), and the contributions in Ahmet H. Köker, ed., Şeyh Bedreddin (1358?-1420) (Kayseri: Erciyes Üniversitesi Matbaası, 1996). 
with mysticism, mystical and Sufi milieux, as well as analysing the useful indications in the text regarding the religious and political networks and alliances he was seeking and establishing. There remain, of course, a number of controversial episodes and assertions in the Menakibname and the other sources which will have to continue to be addressed in future research. These include, among others, the claims for a Seljukite ancestry of Sheikh Bedreddin in the Menabikname, ${ }^{27}$ the exact nature of his encounter with the Orthodox clerics at Chios, ${ }^{28}$ and his claim to the sultanate attributed to him in the Ottoman chronicles (a claim which is rejected in Halîl bin İsmâil's Menakıbname). They will remain the matter of debate like the related historiographic problems of the very likely interrelations between Sheikh Bedreddin's rebellion and the simultaneous revolt of the Ottoman Prince Mustafa Düzme (the False) ${ }^{29}$ or whether Sheikh Bedreddin's Anatolian travels and designs represented an endeavour to form an anti-Ottoman political alliance with the lord of Smyrna (Izmir), Cünayd, and the Anatolian emirates of Karaman and Germiyan. ${ }^{30}$

Exploring the Sheikh Bedreddin and Börklüce Mustafa movements in the wider context of comparable trends in the contemporary Islamic world ${ }^{31}$ can provide some crucial clues to their possible religious provenance, given the extensive trajectories of Sheikh Bedreddin's travels and the increasing evidence of wide-ranging and active mystical-millenarian networks opposed to centralized Timurid rule at that time. ${ }^{32}$ Sheikh Bedreddin's involvement with Hurufi networks, both in their cradle-lands and their extensions in areas under Ottoman control also seem with increasing certainty to be of potentially great importance ${ }^{33}$ in reconstructing his

27 Halîl bin İsmâil, Sımavna Kadısıoğlu Şeyh Bedreddin Manâkıbl, 11-13; on the validity of this claim and Shaykh Bedreddin's quest for political legitimacy, cf. İnalcı, The Ottoman Empire, 188-189; Ahmet Y. Ocak, Osmanlı Toplumunda Zindıllar ve Mülhidler Yahut Dairenin Dışına Çıkanlar (15.-17. Yüzyıllar) (Istanbul: Tarih Vakfı Yurt Yayınları, 2013), 170. 28 Halîl bin İsmâil, Sımavna Kadısıŏ̆lu Şeyh Bedreddin Manâkıbı, 92. On this episode cf. Balivet, Islam mystique et révolution armée, 58-63; Kastritsis, "The Revolt of Şeykh Bedreddin," 230; Salgirlı, "The Rebellion of 1416," 52. Salgirlı considers elements of the narrative a "hagiographical trope", intended to "to adorn the sheikh with a saintly influence that extends even to Christians."

29 Cf. Nedim Filipović, Princ Musa i šejh Bedreddin (Sarajevo: "Svjetlost”, 1971), ch. 10, passim; M. Balivet, "Un épisode méconnu de la campagne de Mehmed 1er en Macédoine: L'apparition de Serrès (1416/819 H.)," Turcica 18 (1986): 137-46; Kastritsis, "The Revolt of Şeykh Bedreddin," 236.

30 Cf. Filipović, Princ Musa i šejh Bedreddin, ch. 10; Çıpa, "Contextualizing Şeykh Bedreddin,” 290; Kastritsis, “The Revolt of Şeykh Bedreddin,” 229-31.

31 An example of such survey may be found in Ahmet Y. Ocak, Osmanlı Toplumunda Zındıllar ve Mülhidler (Istanbul: Tarih Vakfı 1998), 136-202.

32 See now İ. E. Binbaş, Intellectual Networks in Timurid Iran Sharafal-Dīn 'Alì Yazdī and the Islamicate Republic of Letters (Cambridge: Cambridge University Press, 2016).

33 Cf. Balivet, Islam mystique et révolution armée, 42, 51, 54, 108-10; Ocak, Osmanl Toplumunda Zindıllar, 158, 198; Kastritsis, “The Revolt of Şeykh Bedreddin,” 225-26, 227, 231, 238; Siniossoglou, "Sect and Utopia," 44, 51-52. 
religio-political vision and utopianism, given Hurufism's emphatic focus on prophetology, ${ }^{34}$ messianism and apocalypticism, as well as the use of Christian apocalyptic works ${ }^{35}$ in creating the complex and eclectic Hurufi belief system.

All these vistas for future research are also of considerable importance for a better understanding of the continuous reappraisals of and attitudes to the spiritual and ideological legacy of Sheikh Bedreddin in Ottoman culture, religiosities and Sufi traditions. ${ }^{36}$ They could also shed new light on the historical and symbolic afterlife of the Sheikh Bedreddin and Börklüce Mustafa movements in the fifteenth century and in later contexts of religious dissent, non-conformism and sectarianism, including the Sheikh Bedreddin-focused self-identity of some Alevi groups in the Balkans. ${ }^{37}$

One of the interpretations of Börklüce Mustafa's teaching of the communal use of property (as reported in the Doukas account of the rebellion) sees it as reflecting Islamic apocalyptic traditions on the sharing of wealth and abolishing of poverty in the end times. ${ }^{38}$ It is worth noting that as the physical location of the Seven Churches of Asia in Revelation 2-3, the Western Anatolian and the Aegean coastal area played a continuous role in medieval Christian apocalyptic lore, and Smyrna and Philadelphia appear in medieval Christian polemical literature as prominent centres of Christian dissent, heterodoxy and heresy. Important communities or "churches" of the early medieval Paulician movement in Anatolia (at the height of its influence) and high medieval Eastern Christian dualism were located in the region. ${ }^{39}$ As in the case of other Balkan and Anatolian areas, this again raises the inevitable question as to whether there may have been actual historical links and continuity between the earlier outbreaks of Christian dissent and heterodoxy and the later instances of Islamic heterodox and antinomian movements, which spread

34. See now Orkhan Mir-Kasimov, "Ummis versus Imams in the Hurufi Prophetology: an Attempt at a Sunni/Shi'i Synthesis?" in Unity in Diversity: Mysticism, Messianism and the Construction of Religious Authority in Islam, ed. O Mir-Kasimov (Leiden: Brill, 2013), 22147.

35 Orkhan Mir-Kasimov, Words of Power: Hurūfī Teachings between Shi ‘ism and Sufism in Medieval Islam: the Original Doctrine of Fadl Allāh Astarābādì (London: I.B. Tauris/ The Institute of Ismaili Studies, 2015), 427-34.

36 See the preliminary analysis in Abdülbaki Gölpınarlı, Simavna Kadısıoğlu Şeyh Bedreddin (Istanbul: Eti Yayınevi, 1966), 4,2-4,8; Filipović, Princ Musa i šejh Bedreddin, ch. 11. 37 On these groups, cf. N. Gavrilova, "Dvizhenieto na Sheikh Bedredin Mahmud i negovite posledovateli," in Bŭlgarskiiat petnadesetivek, eds. A. Mincheva, B. Raykov and K. Ivanova (Sofia, 1993), 93-107; Frederic de Jong, "Problems concerning the Origins of the Qizilbāş in Bulgaria: Remnants of the Safaviyya?" in Convegno sul tema: La Shi'a nell'Impero Ottomano (Roma, 15 Aprile 1991) (Rome, 1993), 205.

38 Gölpınarlı, Simavna Kadısığlu, 9.

39 See Bernard Hamilton, "The Cathars and the Seven Churches of Asia," in Crusaders, Cathars and the Holy Places, ed. B. Hamilton (Aldershot: Ashgate/Variorum, 1999), 269-95; Yuri Stoyanov, The Other God: Dualist Religions from Antiquity to the Cathar Heresy (London and New Haven: Yale University Press, 2000), 127-31, 195-202. 
and challenged Ottoman authorities in the same or adjacent areas. ${ }^{40}$

Throughout the fourteenth century the Aegean coastal area remained a rather active contact zone of shifting coalitions, frontlines and geopolitics involving the extant regional Byzantine aristocratic and military elites, Muslim and Christian frontier warriors, early Ottomans and their Christian allies, Turkish maritime emirates and the various central and peripheral political or trade players active at that stage in the East Mediterranean and Black Sea areas. This was also a period of intense cross-cultural and cross-religious encounters and interchange for the region which are of undoubted importance for understanding the religious dynamic of the late Byzantine and early Ottoman era in western Anatolia and the southern Balkans.

The Ottoman conquests in Anatolia and the Balkans had already triggered the last phase of Byzantine historical apocalypticism and imperial prophecies which were replete with pronounced eschatological expectations ${ }^{41}$ and deepened the increasing sense of major spiritual crises and dilemmas, especially but not only in the rapidly shrinking Byzantine dominions. Recent research has drawn attention to the potential contribution of contemporary Western apocalypticism to the religious ferment of the period in the Aegean coastal region via the import of sectarian and dissident offshoots of the mendicant orders (mainly the Franciscans) who had been subjected to censure and persecution in Italy. ${ }^{42}$ Such groups, which adopted and fostered extreme forms of Franciscan Joachimism, were reportedly establishing missions and colonies in the East Mediterranean, Near East and Caucasus, including the Aegean coastal zone and islands. ${ }^{43}$

40 Cf. Ahmet Y. Ocak, "Un aperçu général sur l'hétérodoxie musulmane en Turquie: réflexions sur les origines et les caractéristiques du Kizilbachisme (Alévisme) dans la perspective de l'histoire," in Syncretistic Religious Communities in the Near East, eds. K. Kehl-Bodrogi et al. (Leiden: Brill, 1997), 195-205; Ocak, Osmanll Toplumunda Zındıllar, 183; Yuri Stoyanov, "On Some Parallels Between Anatolian and Balkan Islamic Heterodox Traditions and the Problem of their Co-Existence and Interchange with Popular Christianity," in Syncrétismes et hérésies dans l'Orient seljoukide et ottoman des XIIeXVIIle siècles, ed. G. Veinstein (Paris: Peeters Publishers, 2005), 99-101.

41 Cf. Agostino Pertusi, Fine di Bisanzio e fine del mondo. Significato e ruolo storico delle profezie sulla caduta di Costantinopoli in Oriente e Occidente (Rome, 1988), passim; Mitchel Balivet, "Textes de fin d'Empire, récits de fin du Monde: à propos de quelques thèmes communs aux groupes de la zone byzantino-turque," in Les traditions apocalyptiques au tournant de la chute de Constantinople, eds. B. Lellouch and S. Yérasimos (Paris-Montréal, 1999), 5-19; I. Beldiceanu, "Péchés, calamités et salut par le triomphe de l'Islam. Le discours apocalyptique relatif à l'Anatolie (fin XIIIe-fin XVes.)," in Les traditions apocalyptiques au tournant de la chute de Constantinople, eds. B. Lellouch and S. Yérasimos, 19-35; Petre Guran, "Eschatology and Political Theology in the Last Centuries of Byzantiu," Revue des études Sud-est européennes 45/1 (2007), 73-87.

42 K. Zhukov, "Kistorii religioznykh dvizhenii v vostochnom sredizemnomor'e v XIVXV vv.: novaiia interpretatsiia vosstaniia Berkliudzhe Mustafy v Turtsii (okolo 1415 g.)," Pravoslavnyi Palestinskii Sbornik, 98 (35) (1998), 84-98; Zhukov, "Börklüce Mustafa, Was he Another Mazdak," in Syncrétismes et hérésies, ed. Veinstein, 119-29.

43 Analysis of the evidence in Zhukov, "Kistorii religioznykh dvizhenii," 87-89. On the 
Franciscan Joachimism had emerged under the impact of radical forms of the practice of the Franciscan way of life and evangelical poverty and also developed a vigorous critique of the papacy, accompanied by eschatological and millenarian speculations. Eventually this apocalyptic ferment contributed to the emergence of movements such as the followers of Fra Dolcino (the Dulcinians) in north Italy and the Taborites in Bohemia in which an apocalyptic understanding of history was reinforced by radical programmes of violent opposition to church and state authorities, legitimizing military action and armed rebellion. Indeed some of the tenets of the Dulcinian movement invite close parallels to those of the Börklüce Mustafa rebellion: egalitarianism, collectivism, communal use of property, violent opposition to the contemporary political status quo. ${ }^{44}$ Furthermore given the crucial role of the Seven Churches of Asia in Revelation 2-3 and the European sectarian and apocalyptic imaginary, Fra Dolcino identified his immediate predecessor and founder of the socalled "Apostolic Brothers", Gerard Segarelli, with the angel of Smyrna, himself with the Angel of Thyatria and the coming future "Holy Pope" with the Angel of Philadelphia. The presence and routes of similar offshoots of heretical Franciscan Joachimism in the fourteenth-century Aegean coastal area and their potential input in the religious and ideological and cultural struggles and syncretisms during this period will certainly need further close scrutiny. Such scrutiny will need also to address the arguments that Börklüce Mustafa and his followers came under the impact of radicalized Joachimist apocalyptic ideas disseminated in the Aegean coastal region and some of the Aegean islands by the Fraticelli.

This line of enquiry may not only further confirm the apocalyptic nature of the ideals of communal property and voluntary poverty practiced by the Börklüce Mustafa movement, but also indicate that the Sheikh Bedreddin and Börklüce Mustafa uprisings were in some way part of a wider wave and networks of dissenting movements, socio-religious agitation, protest and utopianism which extended from parts of Catholic Europe to the Balkans and Anatolia in the late Byzantine and early Ottoman periods.

stay and activities of Angelo da Clareno (1247-1337), the leader of one of the Fraticelli groups, in Greece, see David Burr, The Spiritual Franciscans: From Protest to Persecution in the Century After Saint Francis (University Park, PA: Penn State Press, 2001), 279-305. 44. Zhukov, "Kistorii religioznykh dvizhenii," 92-93. 


\section{Bibliography}

Anooshar, Ali. The Ghazi Sultans and the Frontiers of Islam: A Comparative Study of late Modern and Early Modern Periods. London and New York: Routledge, 2009.

Babinger, Franz. "Schejch Bedr ed-Dīn, der Sohn der Richters von Simāw.” Der Islam 11 (1921): 1-106.

Barkey, Karen. Empire of Difference: the Ottomans in Comparative Perspective. Cambridge, New York: Cambridge University Press, 2008.

Balivet, Mitchel. "Deux partisans de la fusion religieuse des chrétiens et des musulmans au XVe siècle." Byzantina Thessaloniki 10 (1980): 363-390.

Balivet, Mitchel. Islam mystique et révolution armée dans les Balkans ottomans: Vie du cheikh Bedreddin, le "Hallâj des Turcs", 1358/59-1416 (Vol. 12). Istanbul: Editions Isis, 1995.

Balivet, Mitchel. "Textes de fin d'Empire, récits de fin du Monde: à propos de quelques thèmes communs aux groupes de la zone byzantino-turque." In Les traditions apocalyptiques au tournant de la chute de Constantinople. Edited by B. Lellouch and S. Yérasimos, 5-19. Paris-Montréal, 1999.

Beldiceanu, I. "Péchés, calamités et salut par le triomphe de l'Islam. Le discours apocalyptique relatif à l'Anatolie (fin XIIIe-fin XVe s.)." In Les traditions apocalyptiques au tournant de la chute de Constantinople. Edited by B. Lellouch and S. Yérasimos, 19-35. Paris-Montréal, 1999.

Binbaș, İlker Evrim. Intellectual Networks in Timurid Iran Sharaf al-Dīn 'Alī Yazdi and the Islamicate Republic of Letters. Cambridge: Cambridge University Press, 2016.

Burr, David. The Spiritual Franciscans: From Protest to Persecution in the Century After Saint Francis. University Park, PA: Penn State Press, 2001.

Çıpa, Hakkı E. "Contextualizing Şeyh Bedreddin: Notes on Halīl b. İsmāeîl's Menākıb-ı Şeyh Bedreddīn b. İsrāēil’ (sic).” In Şinasi Tekin’in Anısina: Uygurlardan Osmanlıya, 285-95. Istanbul: Laika Yayıncllık, 2005.

Darling, Linda T. "Contested Territory: Ottoman Holy War in Comparative Perspective.” Studia Islamica 91 (2000): 133-164.

Darling, Linda T. "Reformulating the Gazi Narrative: When Was the Ottoman State a Gazi State?” Turcica 43 (2011): 13-53.

Dayantis, Jean. "Doukas, histoire turco-byzantine. Introduction, traduction et commentaire." PhD diss., Montpellier 3, Lille, 2004.

Doukas, Michaēl. Istoria turco-bizantina (1341-1462). Edited by Vasile Grecu. Editura Academiei Republicii Populaire Romine, 1958.

Eyüboğlu, İsmet Z. Şeyh Bedreddin ve Varidat. Istanbul: Derin Yayıncılık, 1980. Filipović, Nedim. Princ Musa i šejh Bedreddin. Sarajevo: “Svjetlost”, 1971. 
Fodor, Pál. "Ahmedī’s Dāsitān as a Source of Early Ottoman History." Acta Orientalia Academiae Scientiarum Hungaricae 38, no. 1/2 (1984): 41-54.

Gavrilova, N., "Dvizhenieto na Sheikh Bedredin Mahmud i negovite posledovateli." In Bŭlgarskiiat petnadeseti vek. Edited by A. Mincheva, B. Raykov and K. İvanova, 93-107. Sofia, 1993.

Gibbons, Herbert A. The Foundation of the Ottoman Empire: a History of the Osmanlis up to the Death of Bayezid I (1300-1403). Oxford: The Century, 1916.

Gölpınarlı, Abdülbaki. Simavna Kadısıŏ̆lu Şeyh Bedreddin. Istanbul: Eti Yayınevi, 1966.

Guran, Petre. "Eschatology and Political Theology in the Last Centuries of Byzantium.” Revue des études Sud-est européennes 45/1 (2007): 73-87.

Halîl bin İsmâil bin Şeyh Bedrüddin Mahmûd. Sımavna Kadısıŏ̆lu Şeyh Bedreddin Manâkıbı. Edited by A. Gölpınarlı and İ. Sungurbey. Istanbul: Eti Yayınevi, 1967.

Hamilton, Bernard. "The Cathars and the Seven Churches of Asia." In Crusaders, Cathars and the Holy Places. Edited by B. Hamilton, 269-295. Aldershot: Ashgate/Variorum, 1999.

Hasluck, Frederic W. Christianity and Islam under the Sultans, 2 vols. Oxford: Clarendon Press, 1929.

Heywood, Colin. "A Subterranean History: Paul Wittek (1894-1978) and the Early Ottoman State.” Die Welt des Islams 38/3 (1998): 386-405.

Heywood, Colin and Colin Imber, eds. Studies in Ottoman History in Honor of Professor V.L. Ménage. Istanbul: Isis Press, 1994.

Hopwood, Keith. "Christian-Muslim Symbiosis in Anatolia." In Archaeology, Anthropology and Heritage in the Balkans and Anatolia: the Life and Times of F.W. Hasluck, 1878-1920, 3 vols. Edited by D. Shankland, 13-30. Istanbul Isis Press, 2004-2013.

Imber, Colin. "Paul Wittek's De la défaite d'Ankara à la prise de Constantinople." Osmanlı Araştırmaları 5 (1986): 65-81.

Imber, Colin. “The Ottoman Dynastic Myth.” Turcica 19 (1987): 7-27.

Imber, Colin. The Ottoman Empire, 1300-1481. Istanbul: Isis Press, 1990.

Imber, Colin. “The Myth of Osman Gazi.” In The Ottoman Emirate (1300-1389). Edited by E. Zacharoadou, 66-76. Rethymon: Crete University Press, 1993.

İnalcık, Halil. The Ottoman Empire: The Classical Age, 1300-1600. London: Weidenfeld and Nicholson, 1973.

İnalcık, Halil. "The Question of the Emergence of the Ottoman State." International Journal of Turkish Studies 2/2 (1981-1982): 71-79.

İnalcık, Halil. "Introduction: Empire and Population." In An Economic and 
Social History of the Ottoman Empire, 1300-1914. Edited by H. İnalcık and D. Quataert, 11-44. Cambridge: Cambridge University Press, 1994.

Jennings, Ronald C. "Some Thoughts on the Gazi-Thesis." Wiener Zeitschriftfür die Kunde des Morgenlandes 76 (1986): 151-61.

Jong, Frederic de. "Problems concerning the Origins of the Qizilbāş in Bulgaria: Remnants of the Safaviyya?" In Convegno sul tema: La Shi'a nell'Impero Ottomano (Roma, 15 Aprile 1991), 203-16. Rome, 1993.

Kafadar, Cemal. Between Two Worlds: The Construction of the Ottoman State. Berkeley, Los Angeles, London: University of California Press, 1995.

Karamustafa, Ahmet. "Kalenders, Abdâls, Hayderîs: The Formatian of the Bektâşiye in the Sixteenth Century." In Süleyman the Second and his Time. Edited by H. Inalcik and C. Kafadar, 121-129. Istanbul: Isis Press, 1993.

Karamustafa, Ahmet. God's Unruly Friends: Dervish Groups in the Islamic Later Middle Period, 1200-1550. Salt Lake City : University of Utah Press, 1994.

Karamustafa, Ahmet. "Origins of Anatolian Sufism." In Sufism and Sufis in Ottoman Society: Sources, Doctrine, Rituals, Turuq, Architecture, Literature and Fine Arts, Modernisms. Edited by A. Y. Ocak, 67-95. Ankara: Ataturk Supreme Council for Culture, Language and History, 2005.

Kastritsis, Dimitris J. The Sons of Bayezid, Empire Building and Representation in the Ottoman Civil War of 1402-1413. Leiden and Boston: Brill, 2007.

Kastritsis, Dimitris J. "The Revolt of Şeykh Bedreddin in the Context of the Ottoman Civil War of 1402-1413.” In Halcyon Days in Crete VII. Edited by A. Anastasopoulo, 221-238. Rethymno, 2012.

Kiprovska, Maria. "The Mihaloğlu Family: Gazi Warriors and Patrons of Dervish Hospices." Osmanlı Araştırmaları 32 (2008): 173-202.

Kiprovska, Maria. "Byzantine Renegade and Holy Warrior: Reassessing the Character of Köse Mihal, a Hero of the Byzantino-Ottoman Borderland." Journal of Turkish Studies 40 (2013): 245-269.

Kissling, Hans J. “Das Menāqybnāme Scheich Bedr ed-Dīn's, des Sohnes des Richters von Samāvna." Zeitschrift der Deutschen Morgenländischen Gesellschaft 100/1 (1950): 112-176.

Köker, Ahmet H., ed. Şeyh Bedreddin (1358?-1420). Kayseri: Erciyes Üniversitesi Matbaasl, 1996.

Krstić, Tijana. Contested Conversions to Islam: Narratives of Religious Change in the Early Modern Ottoman Empire. Stanford, CA: Stanford University Press, 2011.

Lindner, Rudi P. "Stimulus and Justification in Early Ottoman History." Greek Orthodox Theological Review 27 (1982): 207-224.

Lindner, Rudi P. Nomads and Ottomans in Medieval Anatolia. Bloomington: Indiana University Press, 1983. 
Lindner, Rudi P. Explorations in Ottoman Prehistory. Ann Arbor: University of Michigan Press, 2007.

Lowry, Heath W. The Nature of the Early Ottoman State. Albany: SUNY Press, 2003.

Lowry, Heath W. Fourteenth Century Ottoman Realities (In Search of Haci-Gazi Evrenos). Istanbul: Bahçeşehir University Press, 2012.

Magoulias, Harry J. Decline and Fall of Byzantium to the Ottoman Turks. Detroit: Wayne State University Press, 1975.

Mir-Kasimov, Orkhan. "Ummis versus Imams in the Hurufi Prophetology: an Attempt at a Sunni/Shi'i Synthesis?” In Unity in Diversity: Mysticism, Messianism and the Construction of Religious Authority in Islam. Edited by O Mir-Kasimov, 221-247. Leiden: Brill, 2013.

Mir-Kasimov, Orkhan. Words of Power. Hurūfì Teachings between Shi'ism and Sufism in Medieval Islam: the Original Doctrine of Faḍl Allāh Astarābādī. London: I.B. Tauris / The Institute of Ismaili Studies, 2015.

Ocak, Ahmet Y. Osmanlı Toplumunda Marjinal Sufilik: Kalenderiler, XIV.-XVII. Yuzyıllar. Ankara: Türk Tarih Kurumu, 1992.

Ocak, Ahmet Y. "Un aperçu général sur l'hétérodoxie musulmane en Turquie: réflexions sur les origines et les caractéristiques du Kizilbachisme (Alévisme) dans la perspective de l'histoire.'. In Syncretistic Religious Communities in the Near East. Edited by K. Kehl-Bodrogi et al., 195-205. Leiden: Brill, 1997.

Ocak, Ahmet Y. Osmanlı Toplumunda Zindıllar ve Mülhidler. İstanbul: Tarih Vakfı, 1998.

Ocak, Ahmet Y. Osmanlı Toplumunda Zındıllar ve Mülhidler Yahut Dairenin Dışına Çıkanlar (15.-17. Yüzyıllar). Istanbul: Tarih Vakfı Yurt Yayınları, 2013.

Peacock, A. C. S., De Nicola, Bruno, and Sara Nur Ylldız, eds. Islam and Christianity in Medieval Anatolia. Burlington, VT: Ashgate, 2015.

Pertusi, Agostino. Fine di Bisanzio e fine del mondo. Significato e ruolo storico delle profezie sulla caduta di Costantinopoli in Oriente e Occidente. Rome, 1988.

Salgırl, Saygın. "The Rebellion of 1416: Recontextualizing an Ottoman Social Movement." Journal of the Economic and Social History of the Orient 55 (2012): 32-73.

Shankland, David, ed. Archaeology, Anthropology and Heritage in the Balkans and Anatolia: the Life and Times of F.W. Hasluck, 1878-1920, 3 vols. Istanbul: Isis Press, 2004-2013.

Siniossoglou, Niketas. "Sect and Utopia in Shifting Empires: Plethon, Elissaios, Bedreddin.” Byzantine and Modern Greek Studies 36: 1 (2012), 38-55.

Stoyanov, Yuri. The Other God. Dualist Religions from Antiquity to the Cathar Heresy. London and New Haven: Yale University Press, 2000. 
Stoyanov, Yuri. "On Some Parallels Between Anatolian and Balkan Islamic Heterodox Traditions and the Problem of their Co-Existence and Interchange with Popular Christianity." In Syncrétismes et hérésies dans l'Orient seljoukide et ottoman des XIIe-XVIIIe siècles. Edited by G. Veinstein, 75-119. Paris: Peeters Publishers, 2005.

Terzioğlu, Derin. "Sufis in the Age of State-Building and Confessionalization." In The Ottoman World. Edited by C. Woodhead, 86-100. New York: Routledge, 2011.

Timuroğlu, Vecihi. Varidat. Ankara: Türkiye Yayınları, 1979.

Vryonis, Speros. "The Byzantine Legacy and Ottoman Forms." Dumbarton Oaks Papers 23/24 (1969/1970): 251-308.

Vryonis, Speros. The Decline of Medieval Hellenism in Asia Minor and the Process of Islamization from the Eleventh through the Fifteenth Century. Berkeley: University of California Press, 1971.

Wittek, Paul. The Rise of the Ottoman Empire. London: Routledge, 1938.

Wittek, Paul. "De la défaite d'Ankara à la prise de Constantinople." Revue des etudes Islamiques 12 (1938): 1-34.

Wittek, Paul. The Rise of the Ottoman Empire: Studies in the History of Turkey, 13th-15th Centuries. Edited by C. Heywood. London and New York: Routledge, 2012.

Zachariadou, Elizabeth A. "Religious Dialogue Between Byzantines and Turks During the Ottoman Expansion.” In Religionsgesprache im Mittelalter. Edited by B. Lewis and F. Niewöhner, 295-304. Wiesbaden: Otto Harassowitz, 1992.

Zachariadou, Elizabeth A. "Histoire et légendes des premiers Ottomans." Turcica 23 (1995): 45-89.

Zhukov, K. "Kistorii religioznykh dvizhenii v vostochnom sredizemnomor'e v XIV-XV vv.: novaiia interpretatsiia vosstaniia Berkliudzhe Mustafy v Turtsii (okolo 1415 g.)." Pravoslavnyi Palestinskii Sbornik 98/ 35 (1998): 84-98.

Zhukov, K. "Börklüce Mustafa, Was he Another Mazdak." In Syncrétismes et heresies dans l'Orient seljoukide et ottoman des XIIe-XVIIIe siècles. Edited by G. Veinstein, 119-129. Paris: Peeters Publishers, 2005. 